\title{
Claudia Jullien, Balzac (Honoré de)
}

\section{Marco Stupazzoni}

\section{(2) OpenEdition}

\section{Journals}

\section{Edizione digitale}

URL: http://journals.openedition.org/studifrancesi/36417

DOI: 10.4000/studifrancesi.36417

ISSN: 2427-5856

\section{Editore}

Rosenberg \& Sellier

\section{Edizione cartacea}

Data di pubblicazione: 1 juillet 2005

Paginazione: 185

ISSN: 0039-2944

\section{Notizia bibliografica digitale}

Marco Stupazzoni, «Claudia Jullien, Balzac (Honoré de)», Studi Francesi [Online], 145 (XLIX | I) | 2005,

online dal 30 novembre 2015, consultato il 18 avril 2021. URL: http://journals.openedition.org/ studifrancesi/36417 ; DOI: https://doi.org/10.4000/studifrancesi.36417

\section{Questo documento è stato generato automaticamente il 18 avril 2021.}

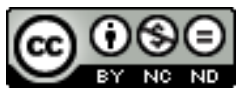

Studi Francesi è distribuita con Licenza Creative Commons Attribuzione - Non commerciale - Non opere derivate 4.0 Internazionale. 


\title{
Claudia Jullien, Balzac (Honoré de)
}

\author{
Marco Stupazzoni
}

\section{NOTIZIA}

CLAUDiA JULlien, Balzac (Honoré de), in AV. VV., Dictionnaire de la Bible dans la littérature française. Figures, thèmes, symboles, auteurs, Paris, Vuibert, 2003, pp. 96-97.

1 Nel riflettere sul progetto mistico-teologico e sul percorso iniziatico dell'uomo verso la perfezione angelica che Balzac illustra nella trilogia del Livre mystique, l'A. osserva che, per lo scrittore, «dont la quête spirituelle reste individualiste et intellectuelle, hors de la «Révélation» hébraïque ou chrétienne, la Bible semble avoir été à la fois beaucoup moins et beaucoup plus qu'un simple répertoire d'images et de symboles» (p. 97). 